\title{
FACTORS AFFECTING STUDENTS' SELF-LEARNING ABILITY AND THE EFFECTIVENESS OF SELF-LEARNING ACTIVITIES
}

\section{NGUYEN VAN THUY}

Research Scholar, Banking Academy of Vietnam, Vietnam

\begin{abstract}
Both theory and practice show that self-learning plays a very important role in human cognitive activities. For university training, self-learning activities of students are considered as indispensable and regular work; furthermore, it is a mandatory requirement and is expressed by a certain proportion of the duration of the course's time structure when applying credit training. This study aims to examine the influence of subjective and objective factors on the effectiveness of students' self-learning activities through the intermediate variable which is self-learning ability. With data collected from 305 regular university students of Vietnam Banking Academy, the study used Structural Equation Model to test the hypotheses of the research model. Research results have shown that there are 6 factors affecting students self-learning efficiency through the variable of self-learning ability. Based on the results, the study provides some policy implications for universities to improve the effectiveness of students' self-learning activities.

KEYWORDS: Self-Learning, Self-learning Motivation, Self-learning Method, Self-learning Time Management, Teaching Method, Self-Learning Support Equipment, Self-Learning Environment, Self-Learning Ability, Self-Learning Performance
\end{abstract}

Received: Jun 09, 2020; Accepted: Jun 29, 2020; Published: Aug 07, 2020; Paper Id.: IJMPERDJUN2020691

\section{INTRODUCTION}

The study of self-learning activities is a topic that attracts a lot of current research. The goal of Vietnamese higher education is to help students master their professional knowledge and practical skills, be able to work independently, creatively and solve academic issues. Self-learning activities in universities help students form and develop self-learning capacity, giving students lifelong self-learning ability. According toBandura (1977), the mission of education systems is to help learners form and develop lifelong learning capacity. In order to do that, it is necessary to identify the factors that affect students' self-learning ability. However, there has not been much empirical research in Vietnam in this issue recently. The purpose of this study is to experimentally identify the factors that affect students' self-learning capacity and self-learning effectiveness, thereby discussing how Vietnamese universities develop strategies to enhance self-learning capacity and the effectiveness of students' selflearning activities.

\section{LITERATURE REVIEW}

\subsection{Self-Learning Ability}

According toLeach (2000), Self-learning ability is the ability and techniques learned by the individual to solve specific situations or the ability to perform self-learning activities. Self-learning capacity includes several components: Orientation ability; performance ability; assessment and application capacity; self- training ability (Trần Bá Hoành, 1998).Self-learning ability is an abstract concept and is influenced by many factors. According to 
the study of Zimmerman and Moylan (2009), Boekaerts (2011),Winne and Hadwin (2012),(Pintrich, Wolters, \& Baxter, 2000), Järvelä, Järvenoja, Malmberg, and Hadwin (2013), Panadero and Järvelä (2015),in order to identify the changes in the factors of self-learning ability after a learning process, the researchers focused on simulating to identify the signs of self-learning ability which are exposed. Many groups of factors affecting self-learning ability identified by the studies include: motivation, self-learning method, self-learning time, teaching method, self-learning support equipment, selflearning environment, etc.

\subsection{Self-Learning Motivation}

Learning motivationare the factors that stimulate and promote positive, continuous learning interest of learners in order to achieve cognitive results, personality development and reachthe set learning goals. Self-learning activities are formed only when learners are self-awared of learning motivation and this is also the need to be aware of the learners themselves, then becoming the motivation for them to study. In other words, the motivation for learning is the one that students carry out learning activities to gain positive learning outcomes. This motivation is expressed by the students' awareness, feeling and attitude towards learning.The study of Zimmerman and Moylan (2009), Boekaerts (2011)have shown that motivation affectsself-learning activities. Therefore, it can be hypothesized:

$\mathbf{H}_{1}$ : Motivation has a positive relationship with self-learning ability

\subsection{Self-Learning Method}

Self-learning method is a way of active, proactive, self-reliant and creative activities in order to realize the quality and effectiveness of certain study and research purposes and tasks. This method consists of the following three basic skill groups: (1) Group of skills in orientingself-learning activities; (2) Group of skills in performingself-learning activities; (3) Group of skillsin examiningand evaluatingself-learning activities ”(Trần Thị Minh Hằng, 2011).Positive self-learning methods will develop active, positive and effective learning capacity of students. The study proposed the hypothesis:

$\mathbf{H}_{2}$ : Self-learning methodhas a positive relationship with self-learning ability

\subsection{Self-Learning Time Management}

To formulate skills, students must spend time onlearning and researchingthemselves. The more self-learning time is, the more excellentthe skills are, and then contributing to the self-learning ability of students. Research of Fredrick and Walberg (1980)have shown that the time spent on self-learning is positively related to academic achievement, but they also argue that this relationship is influenced by the quality of teaching and the ability of students. Research ofVan den Hurk, Wolfhagen, Dolmans, and Van der Vleuten (1998)proposed the relationship between self-learning time and academic achievement, but it is complicated because ofthe influence of many different factors. However, the experimental results for medical freshman and sophomore did not support the hypothesis.

In Vietnam, according to the Regulation on training under credit system No. 43 / 2007 / BGD \& ĐT, students only have $1 / 3$ of the class time instructed by lecturers, the remaining $2 / 3$ of the time students have to study by themselves. To take part in a classroom with instructors, students need 2-3 self-learning hours. It is a compulsory requirement in the structure of students' study hours. In addition, knowledge of any subject is developed through learners' inquiry and the guidance and support of lecturers. If they do not study by themselves, they will only acquire $1 / 3$ of the subject's knowledge, which means that they do not meet the requirements of the subject. Therefore, the study proposes a research hypothesis: 
$\mathbf{H}_{3}$ : Self-learning time management has a positive relationship with self-learning ability

\section{Teaching Method}

Lecturers play a leading role in orienting and stimulating self-learning consciousness for students, timely advising students with teaching methods in the wayof equipping learning styles, promoting students' initiative,applying information and communication technology in teaching, organizingactivities of students in the direction of suggesting, detecting and solving problems. Impact and awareness of students about the importance of activities self-learning will help them to identify the right motivation, awareness, the right learning attitude and proactively develop an appropriate self-learning plan then determiningto applyit inreality (Đỗ Thị Phương Hoa, 2014). Therefore, the study proposes a research hypothesis:

$\mathbf{H}_{4}$ :.Teaching method has a positive relationship with self-learning ability.

\section{Self-Learning Support Equipment}

Students' self-learning activities cannot be performed well if they are not equipped with the necessary material conditions, including: information resource systems such as curricula, reference materials, newspapers and magazines.... which are sufficient in number, rich in content and quality standards; system of classrooms, laboratories - practical - internships, libraries, selflearning areas, applications of ICT...(Võ Thị Ngọc Lan, 2018).Therefore, the study proposes a research hypothesis:

$\mathbf{H}_{5}$ :.Self-learning support equipment has a positive relationship with self-learning ability.

\section{Self-Learning Environment}

Family, school and society are three environments that directly impact student's learning activities. Among them, family plays the role of motivating, supervising and managing students' self-learning activities. Students exposed to the social environment with a spirit and high self-learning capacity will promote self-learning activities of students and vice versa (Đoàn Văn Khái, 2017; Zimmerman \& Moylan, 2009). Therefore, the study proposes a research hypothesis:

$\mathbf{H}_{\mathbf{6}}$ : Self-learning environmenthas a positive relationship with self-learning ability.

\section{Self-Learning Effectiveness}

Self-learning effectiveness is generally determinedas economic, political and social benefits that an individual or an organization gains in its operation. Self-learning effectiveness is the concodancebetween the actual results of self-learning activities and the objectives of self-learning activities(C. K. E. CHENG, 2011). Students with good self-learning ability will achieve high self-learning effectiveness. Therefore, the study proposes a research hypothesis:

$\mathbf{H}_{7}$ : Self-learning ability has a positive relationship with self-learning performance.

\section{The Research Model is Proposed in Figure 1:}

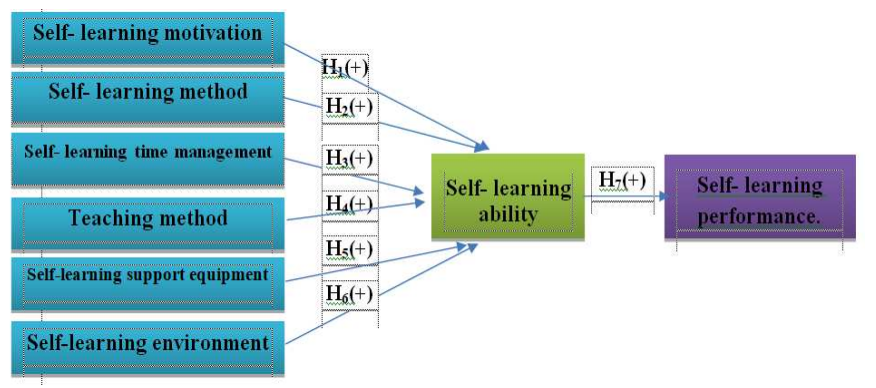

Figure 1: Proposed Research Model. 


\section{RESEARCH METHODS}

\subsection{Measurement}

In this study, these concepts include self-learning motivation, self-learning method, self-learning time management, teaching method, self-learning support equipment, self-learning environment, self-learning ability, self-learning performance will be used as variables in research model. All the scales of these variables are inherited from previous studies and adapted to the context of Vietnam. 5-point Likert scale is used to evaluate these above variables, where 1 is completely disagree and 5 is completely agree.

The scale of the variable self-learning motivation (DCH) is inherited from the scales of Pintrich, Marx, and Boyle (1993), S.-F. Cheng, Kuo, Lin, and Lee-Hsieh (2010), Hammer (2014)which include 04 observed sub-variables. The scale of the variable self-learning method (PPH) is inherited from the scales of Pintrich, Smith, Garcia, and McKeachie (1993), Wild and Schiefele (1994)which include 04 sub-variables. The scale of the variable self-learning time management (TGH) consists of 03 observed sub-variables is inherited from the findings of the study by Diseth and Kobbeltvedt (2010). The scale of the variable teaching method(PPD) is inherited from the research findings ofNokelainen and Ruohotie (2000) which including 04 scales. The scale of the variable self-learning support equipment(HTH) consists of 04 observed variables inherited from the research findings ofSeyhan (2015). The scale of the variable self-learning environment (MTH) consists of 03 observed variables inherited from the research findings of Hammer (2014). The scale of the variable selflearning ability (NLTH) variable is inherited from the research findings ofZimmerman and Moylan (2009), Boekaerts (2011),Winne and Hadwin (2012),Pintrich et al. (2000), Järvelä et al. (2013), Panadero and Järvelä (2015). The scale of the variable self-learning performance (HQTH) variable is inherited from the research findings ofC. K. E. CHENG (2011).

The survey questionnaire was designed based on the conceptual observational variables in the model. In addition, the survey also has demographic questions such as gender, major, student years, GPA

\subsection{Data Collection}

The Sample of the survey is the students from first year to fourth year at Banking Academy of Vietnam in March 2020 with online survey. The samples results include are 305 valid forms included in the analysis.

\subsection{Methodology}

After having the data, SPSS 20 \& AMOS 20 were used to test the hypothesized relationships in the research model as well as evaluate the reliability of measurement scale based on Cronbach Alpha reliability coefficients, EFA and CFA, SEM.

\section{RESULTS}

\subsection{Reliability of Measurement Scales}

A reliability test of scales is performed with Cronbach's Alpha reliability, all observed variables are found to have itemtotal correlations greater than 0.3 and the Cronbach's Alpha reliability coefficient of all factors is greater than 0.6 so the scales of the components DCH,PPH,TGH,PPD,HTH,MTH,NLTH,HQTH are all accepted and included in the next factor analysis. Detailed results assessing measurement scale by Cronbach Alpha reliability is shown in Table 1.

Table 1: Results Assessing Measurement Scale by Cronbach Alpha Reliability

\begin{tabular}{|c|l|c|c|c|}
\hline Id & \multicolumn{1}{|c|}{ Variable } & Code & Number of Observed Variables & Cronbach's Alpha \\
\hline 1 & Self-learning motivation & DCH & 4 & 0.876 \\
\hline 2 & Self-learning method & PPH & 4 & 0.875 \\
\hline
\end{tabular}




\begin{tabular}{|l|l|l|l|c|}
\hline 3 & Self-learning time management & TGH & 3 & 0.802 \\
\hline 4 & Teaching method & PPD & 4 & 0.875 \\
\hline 5 & Self-learning support equipment & HTH & 4 & 0.908 \\
\hline 6 & Self-learning environment & MTH & 3 & 0.826 \\
\hline 7 & Self-learning ability & NLTH & 4 & 0.883 \\
\hline 8 & Self-learning performance & HQTH & 4 & 0.864 \\
\hline
\end{tabular}

\subsection{Exploratory Factor Analysis}

The exploratory factor analysis (EFA) is used to reassess the degree of convergence of observed variables by components. Research on the implementation of KMO test and Bartlett's test in factor analysis shows that KMO coefficient $=0.859>0.5$, Bartlett's test value is significant $($ Sig. $=0.000<0.05)$ indicates that an EFA factor analysis is appropriate (Table 2)

Table 2 shows Indicators all have factor loadings "Factor loading" > 0.5. At Eigen values greater than 1 and with factor extraction used as Principal Axis Factoring (PAF) with Varimax orthogonal rotation, factor analysis extracted 8 factors from 30 observed variables and with the extracted variance at $76 \%$ (greater than $50 \%$ ), which is satisfactory. (Table 3,4)

Table 2: KMO and Bartlett's Test

\begin{tabular}{|l|c|c|}
\hline \multicolumn{2}{|c|}{ Kaiser-Meyer-Olkin Measure of Sampling Adequacy } & .859 \\
\hline \multirow{3}{*}{ Bartlett's Test of Sphericity } & Approx. Chi-Square & 6687.313 \\
\cline { 2 - 3 } & $\mathrm{df}$ & 435 \\
\cline { 2 - 3 } & Sig. & .000 \\
\hline
\end{tabular}

Table 3: Total Variance Explained

\begin{tabular}{|c|c|c|c|c|c|c|}
\hline \multirow{2}{*}{ Component } & \multicolumn{3}{|c|}{ Initial Eigen Values } & \multicolumn{3}{|c|}{ Rotation Sums of Squared Loadings } \\
\hline & Total & \% of Variance & Cumulative \% & Total & $\%$ of Variance & Cumulative \% \\
\hline 1 & 9.277 & 30.923 & 30.923 & 3.335 & 11.116 & 11.116 \\
\hline 2 & 3.186 & 10.619 & 41.541 & 3.151 & 10.502 & 21.618 \\
\hline 3 & 2.723 & 9.077 & 50.619 & 3.150 & 10.498 & 32.116 \\
\hline 4 & 2.055 & 6.849 & 57.468 & 2.997 & 9.989 & 42.105 \\
\hline 5 & 1.822 & 6.072 & 63.540 & 2.994 & 9.979 & 52.084 \\
\hline 6 & 1.501 & 5.004 & 68.544 & 2.639 & 8.796 & 60.880 \\
\hline 7 & 1.223 & 4.076 & 72.620 & 2.366 & 7.886 & 68.766 \\
\hline 8 & 1.141 & 3.805 & 76.424 & 2.298 & 7.659 & 76.424 \\
\hline 9 & .711 & 2.369 & 78.794 & & & \\
\hline 10 & .605 & 2.017 & 80.811 & & & \\
\hline 11 & .585 & 1.951 & 82.762 & & & \\
\hline 12 & .522 & 1.739 & 84.501 & & & \\
\hline 13 & .490 & 1.632 & 86.133 & & & \\
\hline 14 & .434 & 1.445 & 87.578 & & & \\
\hline 15 & .395 & 1.315 & 88.894 & & & \\
\hline 16 & .373 & 1.244 & 90.138 & & & \\
\hline 17 & .357 & 1.189 & 91.327 & & & \\
\hline 18 & .315 & 1.050 & 92.377 & & & \\
\hline 19 & .303 & 1.011 & 93.388 & & & \\
\hline 20 & .289 & .964 & 94.352 & & & \\
\hline 21 & .255 & .851 & 95.204 & & & \\
\hline 22 & .242 & .806 & 96.010 & & & \\
\hline 23 & .231 & .769 & 96.779 & & & \\
\hline 24 & .208 & .694 & 97.473 & & & \\
\hline 25 & .195 & .649 & 98.122 & & & \\
\hline 26 & .164 & .547 & 98.669 & & & \\
\hline
\end{tabular}




\begin{tabular}{|l|l|l|l|l|l|l|}
\hline 27 & .157 & .523 & 99.192 & & & \\
\hline 28 & .138 & .461 & 99.653 & & & \\
\hline 29 & .071 & .236 & 99.889 & & & \\
\hline 30 & .033 & .111 & 100.000 & & & \\
\hline
\end{tabular}

Table 4: Results of Explore Factor Analysis EFA

\begin{tabular}{|c|c|c|c|c|c|c|c|c|}
\hline \multicolumn{9}{|c|}{ Rotated Component Matrix ${ }^{\mathrm{a}}$} \\
\hline & \multicolumn{8}{|c|}{ Component } \\
\hline & 1 & 2 & 3 & 4 & 5 & 6 & 7 & 8 \\
\hline HTH1 & .931 & & & & & & & \\
\hline HTH4 & .922 & & & & & & & \\
\hline HTH3 & .810 & & & & & & & \\
\hline HTH2 & .773 & & & & & & & \\
\hline PPD2 & & .809 & & & & & & \\
\hline PPD4 & & .809 & & & & & & \\
\hline PPD1 & & .794 & & & & & & \\
\hline PPD3 & & .765 & & & & & & \\
\hline PPH3 & & & .844 & & & & & \\
\hline PPH1 & & & .810 & & & & & \\
\hline $\mathrm{PPH} 2$ & & & .763 & & & & & \\
\hline PPH4 & & & .711 & & & & & \\
\hline DCH1 & & & & .813 & & & & \\
\hline $\mathrm{DCH} 3$ & & & & .791 & & & & \\
\hline $\mathrm{DCH} 2$ & & & & .785 & & & & \\
\hline DCH4 & & & & .734 & & & & \\
\hline HQTH4 & & & & & .890 & & & \\
\hline HQTH2 & & & & & .826 & & & \\
\hline HQTH1 & & & & & .804 & & & \\
\hline HQTH3 & & & & & .758 & & & \\
\hline NLTH4 & & & & & & .760 & & \\
\hline NLTH1 & & & & & & .741 & & \\
\hline NLTH3 & & & & & & .712 & & \\
\hline NLTH2 & & & & & & .635 & & \\
\hline MTH2 & & & & & & & .872 & \\
\hline MTH3 & & & & & & & .858 & \\
\hline MTH1 & & & & & & & .759 & \\
\hline TGH3 & & & & & & & & .811 \\
\hline TGH2 & & & & & & & & .802 \\
\hline TGH1 & & & & & & & & .683 \\
\hline
\end{tabular}

Extraction Method: Principal Component Analysis.

Rotation Method: Varimax with Kaiser Normalization.

a. Rotation converged in 6 iterations.

\subsection{Confirmatory Factor Analysis (CFA) and Structural Equation Model (SEM)}

Confirmatory Factor Analysis (CFA): Based on the result of EFA: 6 factors (22 observed variables) affecting successful self-learning ability (4 observed variables), self-learning ability impacts on self-learning performance (4 observed variables), study Confirmatory factor analysis (CFA) by AMOS 20 software. Result of the CFA has all observed variable's weight are allowed standard $(>=0.5)$ so that scale achieves convergence value ((Anderson \& Gerbing, 1988)). The Result of CFA is shown in the following Figure 2:

SEM Structural Equation Model: SEM analysis was performed on AMOS 20 software of which the results are shown in Figure 3. 
The SEM results (Figure 2) show that the weights of the observed variables all reached the standard level allowed $(>=0.5)$ and statistically significant with the $p$-values all equal to 0.000 . Thus, it is possible to conclude that the observed variables used to measure the component variables of the scale achieved convergent validity. SEM shows that the model has 383 degrees of freedom, chi-squared test statistic $=1082.071$ with $p$-value $=0.000<0.05$; Chi-square $/ \mathrm{df}=2.825$ which satisfies the $<3$ requirement and indicators show that the model is compatible with market data $(\mathrm{CFI}=0.892$; TLI $=$ 0.878; GFI $=0.814$ and RMSEA $=0.077<0.08$ ). The components of the variables DCH, PPH, TGH, PPD, HTH, MTH, NLTH, and HQTH have no correlation between the errors of the observed variables, so they all achieve the unidirectional property. In addition, the study examined the discriminate value of concepts in the model. The results show that the concepts in the model achieve discriminate validity.

Hypotheses Testing: From the testing results from the non-standardized regression table (Table 7) shows the significance level of $5 \%$ (95\% confidence level), the testing value of the relationship is statistically significant (P value < $0.05=* * *)$, it can be concluded that the hypotheses $\mathrm{H}_{1}, \mathrm{H}_{2}, \mathrm{H}_{3}, \mathrm{H}_{4}, \mathrm{H}_{5}, \mathrm{H}_{6}, \mathrm{H}_{7}$ are approved.

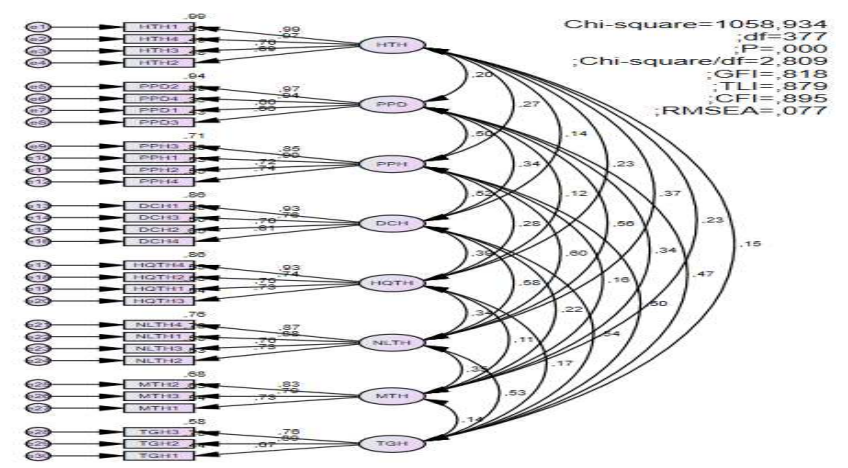

Figure 2: CFA Model.

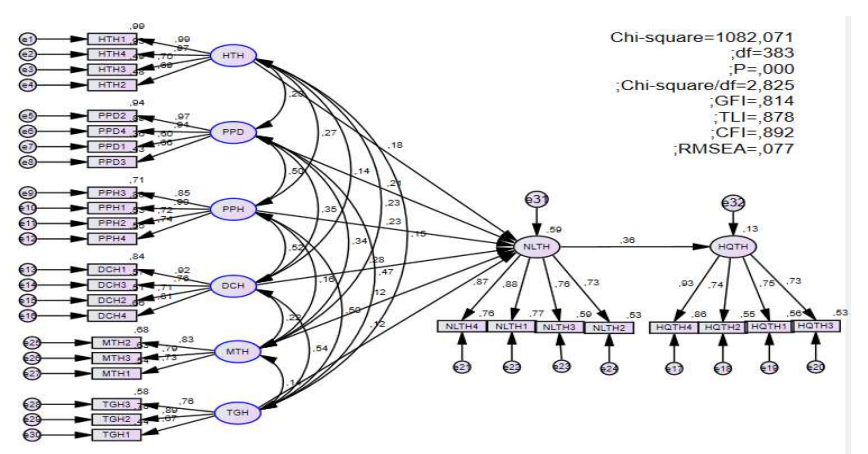

Figure 3: Analysis Results Structural Equation Model.

Table 5: Standardized Regression Weights

\begin{tabular}{|c|c|c|c|}
\hline \multicolumn{3}{|c|}{ Path } & Estimate \\
\hline DCH & $--->$ & NLTH &, 281 \\
\hline PPH & $--->$ & NLTH &, 227 \\
\hline PPD & $--->$ & NLTH &, 211 \\
\hline HTH & $--->$ & NLTH &, 184 \\
\hline TGH & $--->$ & NLTH &, 119 \\
\hline MTH & $--->$ & NLTH &, 118 \\
\hline NLTH & $--->$ & HQTH &, 355 \\
\hline
\end{tabular}

Source: SEM analysis results 


\section{DISCUSSIONS}

Self-learning ability is the ability to think, use knowledge, apply skills and necessary qualities in the process of independence, initiative, self-awareness, creativity in learning, exploring and researching in order to grasp, cultivate, and improve knowledge and skills. Each person's self-learning ability is different, and the difference depends on many subjective and objective factors, which are also known as internal factors (from the learners themselves) and external factors.

This study explores the factors affecting self-learning ability and tested the relationship between self-learning ability and self-learning performance. Self-learning motivation, self-learning method, self-learning time management, teaching method, self-learning environment, self-learning support equipment positively affect self-learning ability. Selflearning ability also positively affects self-learning performance. This result is consistent with published studies

Research results show that the 06 factors include self-learning motivation, self-learning method, self-learning time management, teaching method, self-learning environment, self-learning support equipment affect self-learning ability in descending levels of impact. Among six factors, Self-learning motivation has the greatest positive impact on self-learning ability at coefficient of 0.281 (Table 5). This factor is decisive, because learning must stem from the needs of the students, they have to be aware of what they need and want to achieve. If students do not identify their decisive role in the success or failure of self-learning process, self-learning activities will not succeed. Only when the purpose is clearly determined with a good learning attitude, will students be able to promote their learning ability and achieve high results.

Self-learning method has the second greatest positive impact on self-learning ability at 0.227 standard units (table 5). Learning method is the way students work in the process of receiving, discovering and processing information to form knowledge and skills. The method of learning is also very important for learning outcomes. If students find the right learning method for themselves, with the training method and subject characteristics, the acquisition will be convenient, without taking too much effort and time; therefore the learning effectiveness will be high. Since then, it stimulates and promotes the potential in every person. Proactive learning methods will promote the development of students' self-learning skills and help them to develop the ability of self-learning for a lifetime..

One of the important results of this research is to show that the teaching method of teachers directly affects student's self-study ability. According to the research results, the teaching method of teachers has the 3rd influence on the self-study ability of students and has a standardized coefficient of 0.211 . Teaching methods of lecturer's Play a very important role and directly affect students' self-study. If lecturers apply active teaching methods, act as an instructor, promote students' self-study, ask students to actively read and exploit resources, intensify discussion; examinations and tests do not except for those parts that lecturers require to read, it will surely enhance students' self-study abilities. On the other hand, students' self-study spirit also depends on the way that the lecturers instruct and guide students about the purpose and motivation of learning, learning methods, self-testing and self-evaluating effectively.

The fourth factor affecting students' self-study ability is the support equipment with standardized coefficient of 0.184 . These are libraries, reading rooms and self-study rooms, computers, Internet systems, study areas, learning materials that students can access during the self-study process. The factors managing the self-study time and the self-study environment significantly influence the students' self-study ability with standardized coefficients, respectively, 0.119 and 0.118 . The optimal management of students 'self-study time, the regular allocation of time throughout the semester and a specific plan for self-study activities will promote the effectiveness of students' self-study activities and build active attitude towards learning. In addition, the self-study 
environment has a significant influence on students' self-study activities. Family have a role to motivate, take care and urge students to self-study, then creating conditions for students to have more opportunities for to form self-discipline, initiative and creativity in self-study activities. In addition, interacting with people who have high spirits and self-study ability will have positive influence on students' self learning. Therefore, students become more motivated to improve their ability to self- study.

The research results also showed the impact of students' self-study capacity on the effectiveness of self-study activities with a standardized impact coefficient of 0.355 . Students with good self-study ability will promote high selfstudy activities in all aspects such as developing active learning skills, developing effective learning methods, and improving learning outcomes.

\section{CONCLUSIONS}

The research results are empirical evidence showing the strong impact of many factors on students' self-learning ability such as: self-learning motivation, self-learning method, self-learning time management, teaching method, self-learning environment, self-learning support equipment. Among them, self-learning motivation and self-learning method are the two most influential factors. The study also measures the impact of self-learning capacity on student self-learning performance.

Based on the research results, a number of solutions are proposed to help Vietnamese universities improve the self-learning capacity and the effectiveness of students' self-learning activities as follows:

The first solution is the one that comes from the students themselves. It is essential to help students identify the right motivation and right learning goals; to guide students to have active, positive and effective learning methods; to guide students to plan and to manage their self-learning time effectively.

The second solution comes from universities: Universities need to improve the regulations, processes of management, support, testing and evaluation of students' self-learning activities; Universities need to increase infrastructure investment, equipment to support students' self-learning activities, enhance learning resources, especially digital resources so that students can access anytime, anywhere in the process of self-learning; Universities also need to strengthen activities to support students in self-learning activities such as workshop, seminars, clubs which share positive, proactive and effective self-learning methods.

The third solution comes from lecturers. Lecturers should proactively share and guide the effective, proactive selflearning methods for each module; and in each module, it is necessary to specify the contents of self-learning., Lecturers should support, manage, control as well as evaluate students' self-learning results in those sections; enhance the content of discussion so that students can research and present results to themselves and other students to stimulate students' active self-learning In addition, lecturers need specific instructions for learning resources for students.

The limitation of the study is that the sample is still small and was conducted among students of Banking Academy, Vietnam. In the future, the research may develop in the direction of: (1) Researching for each type of student according to different types of major of different universities (2) Additional research on factors affecting self-learning capacity and self-learning performance.

\section{ACKNOWLEDGMENT}

This research is funded by the Banking Academy under grant number DTHV.42.2020. Sincere thanks to the Banking Academy students for their enthusiastic participation in the research process 


\section{REFERENCES}

1. Anderson, J. C., \& Gerbing, D. W. (1988). Structural equation modeling in practice: A review and recommended two-step approach. Psychological bulletin, 103(3), 411.

2. Bandura, A. (1977). Self-efficacy: toward a unifying theory of behavioral change. Psychological review, 84(2), 191.

3. Boekaerts, M. (2011). Emotions, emotion regulation, and self-regulation of learning. Handbook of self-regulation of learning and performance, 5, 408425 .

4. CHENG, C. K. E. (2011). The role of self-regulated learning in enhancing learning performance.

5. Cheng, S.-F., Kuo, C.-L., Lin, K.-C., \& Lee-Hsieh, J. (2010). Development and preliminary testing of a self-rating instrument to measure self-directed learning ability of nursing students. International journal of nursing studies, 47(9), 11521158.

6. Diseth, A., \& Kobbeltvedt, T. (2010). A mediation analysis of achievement motives, goals, learning strategies, and academic achievement. British Journal of Educational Psychology, 80(4), 671687.

7. Đỗ Thị Phưong Hoa. (2014). Vai trò của giảng viên trong việc nâng cao năng lục tụ học của sinh viên đáp ứng yêu cầu đào tạo theo học chế tín chỉ. Dạy và Học sáng tạo, 6, 5860.

8. Đoàn Văn Khái. (2017). Nâng cao năng lực tụ học của sinh viên truoòng đại học ngoại thuoong. Tạp chí Kinh tế Đối Ngoại, 95(95).

9. Fredrick, W. C., \& Walberg, H. J. (1980). Learning as a function of time. The journal of educational research, 73(4), 183194.

10. Hammer, N. L., Jan Marco, (2014). Internationalization of eLearning-Consideration of Culture-specific Differences of Selfdirected Learning Ability.

11. Järvelä, S., Järvenoja, H., Malmberg, J., \& Hadwin, A. F. (2013). Exploring socially shared regulation in the context of collaboration. Journal of Cognitive Education and Psychology, 12(3), 267286.

12. Leach, L. J. (2000). Self-directed learning: Theory and practice.

13. Nokelainen, P., \& Ruohotie, P. (2000). Modern Modeling of Student Motivation and Self-Regulated Learning.

14. Panadero, E., \& Järvelä, S. (2015). Socially shared regulation of learning: A review. European psychologist.

15. Pintrich, P. R., Marx, R. W., \& Boyle, R. A. (1993). Beyond cold conceptual change: The role of motivational beliefs and classroom contextual factors in the process of conceptual change. Review of Educational research, 63(2), 167199.

16. Pintrich, P. R., Smith, D. A., Garcia, T., \& McKeachie, W. J. (1993). Reliability and predictive validity of the Motivated Strategies for Learning Questionnaire (MSLQ). Educational and psychological measurement, 53(3), 801813.

17. Pintrich, P. R., Wolters, C. A., \& Baxter, G. P. (2000). 2. Assessing metacognition and self-regulated learning.

18. Seyhan, H. G. (2015). Effects of Self-regulatory Strategy on Prospective Science Teachers' Chemistry Self Efficacy According to Class Level and Gender. Journal of Education and Training Studies, 4(3), 97117.

19. Trần Bá Hoành. (1998). Vị trí của tụ học tụ đào tạo trong quá trình dạy học giáo dục và đào tạo. Tạp chí Nghiên cúu giáo dục.

20. Trần Thị Minh Hằng. (2011). Tụ học và nhũng yếu tố tâm lí co bản trong tụ học của sinh viên su phạm. Hà Nội: NXB Giáo duc Việt Nam.

21. Van den Hurk, M., Wolfhagen, H., Dolmans, D., \& Van der Vleuten, C. (1998). The relation between time spent on individual study and academic achievement in a problem-based curriculum. Advances in Health Sciences Education, 3(1), 4349. 
22. Võ Thị Ngọc Lan, L. T. P. H. (2018). Hoạt động tụ học của sinh viên năm nhất Khoa Điện tử-Viễn thông Truờng Đại học Sài Gòn. Tạp chí Khoa họ, 15(4), 108.

23. Wild, K.-P., \& Schiefele, U. (1994). Lernstrategien im Studium: ergebnisse zur Faktorenstruktur und Reliabilität eines neuen Fragebogens. Zeitschrift für differentielle und diagnostische Psychologie.

24. Winne, P. H., \& Hadwin, A. F. (2012). The weave of motivation and self-regulated learning. In Motivation and self-regulated learning (pp. 309-326): Routledge.

25. Zimmerman, B. J., \& Moylan, A. R. (2009). Self-regulation: Where metacognition and motivation intersect. In Handbook of metacognition in education (pp. 311-328): Routledge.

26. TARIQ, MUHAMMAD USMAN, SHAHZIA KHAN, and ZEHRA C. ARACI. "SELF-DIRECTED LEARNING THROUGH YOUTUBE: CHALLENGES, OPPORTUNITIES, AND TRENDS IN THE UNITED ARAB EMIRATES." International Journal of Mechanical and Production Engineering Research and Development (IJMPERD) 10.3 (2020):1949-1966.

27. Chuang, Hui-Chun. "Self-Regulated Learning of Architectural Design Professionals in Taiwan." International Journal of Educational Science and Research (IJESR) 7.2 (2017): 113124.

28. Potphode, Seema, and Zareen Baksh. "COMPARATIVE STUDY OF EFFECTIVENESS OF INQUIRY TRAINING MODEL WITH TRADITIONAL TEACHING IN TERMS OF CREATIVITY OF MIDDLE SCHOOL STUDENTS." International Journal of Humanities and Social Sciences (IJHSS) 8.3 (2019):117124.

29. Varshini, Nallala Hima, and RAJA AMBETHKAR. "Improving Oral Communication through Direct Method in Rural Schools of Telangana." International Journal of English and Literature (IJEL) 8.1 (2018): 4548. 

